\title{
Quarantine and Prevention of Diseases Ordinance: is it sufficient for public health response in COVID-19?
}

\author{
S Mahendra Arnold \\ Ministry of Health, Sri Lanka \\ *Correspondence: mahendra_arnold@yahoo.com \\ DOI: https://doi.org/10.4038/jccpsl.v26i3.8332
}

https://orcid.org/0000-0001-7746-8515

Received on 14 May 2020

Accepted on 22 May 2020

\section{Background}

Legislation on quarantine runs back to the $18^{\text {th }}$ century. Quarantine and Prevention of Diseases Ordinance No.3 of 1897 is one of the oldest among currently imposed legal enactments in Sri Lanka. The control of global pandemics like smallpox, plague and cholera required specific legislative provisions. Such introduction of new diseases and disease control measures at points of entry and in the community necessitated the amendment of the Ordinance from time to time. It was amended in 1917, 1919, 1920, 1936, 1939, 1941, 1943, 1952 and 2005. Under Sections 2 and 3 of the Ordinance, the Minister of Health is vested with the power to bring in regulations for the purpose of preventing the introduction and spread of any disease in and outside of Sri Lanka. Accordingly, several regulations have been enacted for the above purpose.

\section{Scope of the legislation}

This legislation covers a wide scope. There are specific regulations pertaining to specific diseases such a plague, smallpox, cholera, yellow fever and ancylostomiasis. They were enacted during periods of epidemics/pandemics to give legality for the disease control measures adopted. In addition, the legislation has a wide spectrum of common provision which can be applied to any infectious or contagious diseases. The Quarantine and Prevention of Diseases Ordinance No.3 of 1897 and regulations made thereunder have given special attention to points of entry. Regulating the health aspect in points of entry in any country is very important in preventing introduction of infectious and contagious diseases to the country. Under the Quarantine and Prevention of Diseases Ordinance, two separate regulations have been enacted for points of entry, namely airports and seaports.

\section{Authority to implement}

The Director General of Health Services (DGHS) is the main Proper Authority. The Proper Authority can delegate powers to any person and authorize in writing to implement the provision of the legislation. For example, at the early stage of the disease, the DGHS delegated the powers to medical officers of health $(\mathrm{MOH})$ and public health inspectors $(\mathrm{PHI})$ to implement the provisions under the legislation to prevent and control COVID-19 in Sri Lanka. Further, to facilitate the significant role played in assisting the disease control activities in the field, activities of the Police Force were legitimized by a power delegation by the DGSH under the guidance of health authorities. 


\section{Specific requirements for COVID-19 public health response}

COVID-19 was declared as a Public Health Emergency of International Concern (PHIEC) by the World Health Organization on 30 January 2020. The disease was rapidly spreading in countries outside China where the disease originated. Unrestricted global travel resulted in introduction of the disease to a large number of countries. Highly contagious nature of the virus and lapses in preventive and control measures resulted in rapid community transmission in some countries. In view of this and limited knowledge on the novel viral disease, it was required to take common and specific measures to prevent introduction of this viral disease. Since international travel was the mode of introduction of the disease to a country, points of entry should be strengthened.

Being an island, Sri Lanka has a special advantage of being able to easily restrict the entry to the country. Airports and seaports are the points of entry for international travellers to Sri Lanka, which include five seaports (Colombo, Galle, Hambantota, Trincomalee and Norochchole) and four airports (Katunayake, Ratmalana, Mattala and Jaffna). For the purpose of prevention of entry of disease, policy decisions on travel restrictions, quarantining and implementation of specific provisions applicable to points of entry in the Ordinance were required. The government took several policy decisions to be implemented at the points of entry. At the initial stage of the epidemic, all passengers coming from China were subjected to thermal screening and later this was extended to passengers coming from the Republic of Korea where there was rapid community spread. On 10 March 2020, a policy decision was taken to quarantine travellers entering Sri Lanka from the Republic of Korea, Italy and Iran. They were sent for 14 days mandatory quarantine in quarantine centres. A travel ban was implemented to these three countries from 14 March and by 15 March, it was extended to France, Spain, Germany, Switzerland, Denmark, Netherlands, Sweden and Austria. The United Kingdom, Belgium and Norway were added on 17 March and on 18 March, Qatar and Bahrain were added to the travel ban country list. On 19
March, all passenger arrivals to Sri Lanka were suspended.

In the event of a disease being introduced to the country, there are specific measures stipulated in the Ordinance to control and prevent its spread. They include surveillance, disease investigation, isolation, quarantining, treatment, restriction of movements and notification.

\section{Important legal provisions used for control of COVID-19}

There are many legal provisions under the Quarantine and Prevention of Diseases Ordinance which can be directly applied to prevent and control COVID-19.

Declaration of a diseased locality: Diseased locality is any locality infected or suspected of being infected with disease. Proper Authority has the powers to declare a locality as a diseased locality. In COVID19 , the declaration of disease locality is important since restriction of movement can be done in a disease locality by the Proper Authority. This provision was implemented on 18 March 2020 by the Director General of Health Services by declaring the entire Sri Lanka as a diseased locality for COVID-19.

Prohibition of entering and leaving diseased locality: Under this provision, no person can enter or leave the diseased locality without the permission of Proper Authority. Following the declaration of diseased locality on 18 March 2020, the movements of persons in the diseased locality was prohibited. Although, this was known as "curfew", it was in fact restriction of movements in the diseased locality directed by the Proper Authority.

Declaration of place of infected: Proper Authority can declare a place as infected. No person shall enter or leave a house or place infected with disease without the permission of Proper Authority. This provision is important especially in a situation where the capacity of hospitals exceeds due to large number of cases. The burden of the curative sector can be reduced if asymptomatic or mild cases stay in their place of residence and seek hospital admission only 
when the condition deteriorates. By declaring the premises as place of infected, the movements of the inhabitants are restricted. Inhabitants cannot go out of the premises and outsiders cannot enter the premises without the sanction of the Proper Authority. If community transmission occurs in Sri Lanka and the number of cases increases beyond the threshold of the curative sector, it may be necessary to keep the asymptomatic and mild cases in their place of residence using this provision.

Removal of diseased or suspected to be diseased: Proper Authority can remove a person who is diseased or suspected of diseased to public hospitals or any other place provided for such purpose. The public health staff in certain instances faced the challenge of refusal of persons especially close contacts or persons with symptoms to be removed to a quarantine centre. The $\mathrm{MOH}$ has the power to remove any such person with the assistance of the police or any other persons deemed necessary.

Restriction of movements: Persons suffering from infectious, contagious or epidemic diseases are prohibited from going into a public street or place. This provision is important to prevent the disease spread. In Sri Lanka currently, most of the diagnosed COVID-19 cases are asymptomatic. If the case load increases and asymptomatic and mild patients are managed in the community, this provision is useful for health authorities to prevent patients entering public streets or public places.

Right of entry: Proper Authority or authorized persons can enter any house or premises for the purpose of inspecting the place or to carry out provisions framed under the Ordinance. This is a very important provision specialty for the $\mathrm{MOH}$ and $\mathrm{PHI}$ in instances where the public do not corporate with disease surveillance and investigations. The health authorities can enter any premises in a reasonable time with or without the consent of owner or occupier.

Place under observation or surveillance: Proper Authority can place under observation or surveillance any person arriving in Sri Lanka within the quarantinable period from an infected area, persons who are contacts of a quarantinable disease and persons returning from a pilgrimage. This provision is useful for home or institutional quarantining of suspected COVID-19 patients.

Quarantining for further period: If a case is found with quarantined persons, a further period of quarantine of the contacts of the cases should be done. This provision was useful especially in quarantine centres. Most of the quarantine centres did not have individual rooms. If a person in a group of persons housed together in the centre becomes COVID-19 positive within the period of stay in the centre, the entire group was quarantined for a further period of 14 days.

Human remains: Human remains of COVID-19 patients or suspected patients should be cremated. Under this new provision all COVID-19 deaths or suspected deaths are cremated.

Occupying premises: Proper Authority can occupy any premises for the purpose of isolation or quarantine. The DGHS occupied premises to be used as quarantine centres under this provision. The first government institution which was occupied to set up quarantine centres for COVID-19 was the Leprosy Hospital, Hendala while Batticaloa campus was the first private owned premises acquired.

Closing of schools: Proper Authority can order the closure of schools for any length of time. COVID-19 being a highly contagious disease, schools remain a highly vulnerable setting. Under this provision, the DGHS has the authority to close down schools if the need arises.

Requirement to perform duties: No employee can withdraw from his duties. During an epidemic of a highly contagious disease, there is a possibility of healthcare or other staff of essential services to keep away from duty. This issue has been addressed in the Quarantine and Prevention of Diseases Ordinance where employees are prohibited from withdrawing from duties.

Punishment: Any person guilty of an offence against the Ordinance shall be liable on conviction before a 
Magistrate to imprisonment not exceeding six months or a fine not exceeding Rs. 10,000/= or both.

\section{Challenges and measures taken to address gaps}

COVID-19 is a novel disease, thus was not initially enlisted as a quarantinable disease. Although the provisions on contagious, infectious and epidemic nature can still be applied to COVID-19, declaring COVID-19 as a quarantinable disease would widen the scope of provisions that can be applied. In order to address this gap, Coronavirus disease-2019 was named as a quarantinable disease through an Extraordinary Gazette notification published on 20 March 2020.

The provisions of the Ordinance are implemented mainly by the directions of the Proper Authority. Most of the designations of Proper Authorities in the existing regulations were redundant. The MOHs, medical officers in seaports and airports who implement and give directions on implementation of the provisions at the ground level were not clearly named as proper authorities. Through a regulation published on 25 March, the lapses in the provisions on Proper Authority were rectified. The MOHs and additional MOHs were named the Proper Authorities for their respective $\mathrm{MOH}$ areas, while medical officers of the Airport Health Office and Port Health Office were named as Proper Authority for the respective airport or seaport.

Due to the lack of scientific evidence on the spread of disease through ground water contamination, the health authorities opted for cremation as a safe approach on disposal of human remains of COVID19 patients. The existing regulations had provisions either for burial or cremation. Based on this new requirement, a new regulation was enacted through a gazette notification published on 11 April 2020 stipulating mandatory cremation of human remains of suspected or confirmed COVID-19 patients.

During implementation of specific COVID-19 preventive measures such as the use of face mask, maintaining physical distance, hand sanitisation, home quarantining etc, there was lack of legal cover for the implementing authorities. In order to address this gap, a new regulation was enacted through a gazette notification published on 15 October 2020 stipulating provisions on COVID-19 preventive measures.

The implementation of prevention and control method at the community level is a challenge especially with the direct involvement of non-health sectors. There were instances where the health sector was by-passed in decision making. By appointing MOHs as Proper Authority, the legal authority for decision making in implementing the provision of legislation was entrusted to the Proper Authority. Further delegation of powers to the Police Force was done subject to the guidance of $\mathrm{MOH}$, who is the local Proper Authority.

\section{Way forward}

The Quarantine Ordinance can be considered as a time-tested legislation which has been effectively used for prevention and control of many diseases over a century. It consists of general provisions which can be applied to emerging diseases. There may be gaps to address specific new disease conditions. For COVID19, the Ministry of Health brought in specific regulations to address these gaps. As the disease progresses, new knowledge of the disease will be available. At present, the Ministry of Health is in the process of drafting a new regulation specifically for COVID-19 incorporating additional provision which would further facilitate the control and prevention of this novel viral disease.

\section{Reference}

Quarantine and Prevention of Diseases Ordinance. No.03 of 1897. Legislative enactments of the Democratic Socialist Republic of Sri Lanka. Chapter 222.

Quarantine and Prevention of Diseases Ordinance. No.03 of 1897. Legislative enactments of the Democratic Socialist Republic of Sri Lanka. Vol XVII, Chapter 553.

The Ceylon Government Gazette, No. 7484, 28 August 1925

The Ceylon Government Gazette No. 7991, 7 July 1933. 
The Ceylon Government Gazette, Extraordinary No. 8220, 7 May 1936.

The Ceylon Government Gazette, No. 9175, 13 August 1943.

The Ceylon Government Gazette, No. 9570, 21 June 1946.

The Ceylon Government Gazette, No. 10713, 17 September 1954.

The Ceylon Government Gazette, No. 10593, 2 October 1953.
The Ceylon Government Gazette, No. 12125, 6 May 1960.

The Gazette of the Socialist Republic of Sri Lanka, Extraordinary, No 2167/18,20 March 2020.

The Gazette of the Socialist Republic of Sri Lanka, Extraordinary, No 2168/6, 25 March 2020.

The Gazette of the Socialist Republic of Sri Lanka, Extraordinary, No 2170/8, 11 April 2020.

The Gazette of the Socialist Republic of Sri Lanka, Extraordinary, No 2197/25, 15 October 2020. 